\title{
Japanese Conversation Learning through 'Active Learning' for Yafsi Volunteers in Medan
}

\author{
(Pembelajaran Percakapan Bahasa Jepang Melalui Active Learning bagi Relawan Yafsi di \\ Medan)
}

\author{
Mhd. Pujiono ${ }^{* 1}$, Budi Agustono ${ }^{2}$, Murniati Br. Barus ${ }^{3}$ \\ 1,2,3 Faculty of Cultural Sciences, Universitas Sumatera Utara; Jl. Universitas No. 19, Medan \\ *e-mail: mhd.pujiono@usu.ac.id
}

\begin{abstract}
This Community service activities regarding 'Basic Japanese Language Conversation Learning (Nihongo no Kaiwa) through active learning for Yayasan Fajar Sejahtera Indonesia (YAFSI) volunteers in Medan' is an appropriate activity in improving the foreign language qualifications of volunteers who are active in the community. YAFSI is a foundation engaged in the field of community empowerment, specifically women's empowerment and child protection in Medan. In this service, the team in collaboration with the YAFSI has held Japanese language conversation training with active learning methods for one month. The active learning method is proven able to facilitate the emergence of life skills. This learning leads to optimizing the intellectual and emotional involvement of students in the learning process, directed to learn students to learn to obtain and process the acquisition of learning through knowledge, skills, attitudes and values. After the training was conducted, the community service team also provided assistance with Japanese learning literature materials.
\end{abstract}

Keywords: active learning, Japanese, YAFSI volunteers

\begin{abstract}
Abstrak
Kegiatan pengabdian kepada masyarakat Pembelajaran Percakapan Bahasa Jepang (Nihongo no Kaiwa) Tingkat Dasar melalui active learning bagi relawan Yayasan Fajar Sejahtera Indonesia (YAFSI) di Medan merupakan suatu kegiatan yang tepat dalam meningkatkan kualifikasi berbahasa asing para relawan YAFSI yang banyak bergerak di lingkungan masyarakat. YAFSI merupakan yayasan yang bergerak dalam bidang pemberdayaan masyarakat, khususnya pemberdayaan perempuan dan perlindungan anak di kota Medan. Dalam pengabdian ini, tim bekerja sama dengan Yayasan Fajar Sejahtera Indonesia (YAFSI) telah mengadakan pelatihan percakapan bahasa Jepang dengan metode active learning selama satu bulan. Metode active learning adalah metode yang terbukti mampu memfasilitasi munculnya perilaku life skills atau keterampilan hidup. Pembelajaran ini mengarah pada pengoptimalisasian pelibatan intelektual dan emosional relawan YAFSI dalam proses pembelajaran, diarahkan untuk membelajarkan peserta didik untuk belajar memperoleh dan memproses perolehan belajarnya melalui pengetahuan, keterampilan, sikap dan nilai. Setelah pelatihan dilaksanakan, tim pengabdian kepada masyarakat juga membantu memfasilitasi literatur pembelajaran bahasa Jepang.
\end{abstract}

Kata kunci: active learning, bahasa Jepang, relawan YAFSI

\section{INTRODUCTION}

Language is needed to be able to interact and communicate with others. Language can be interpreted as a tool to convey something that crossed the heart (Murti, 2015, p. 177). With language, a person can interact or communicate with others, both to convey desires, feelings, opinions, ideas, experiences, and knowledge. The role of language in humans is very important. In almost all activities, humans need language assistance. In the MEA era language became an important factor in communication (Rondiyah et al., 2017, p. 142).

In addition, in the era of the industrial revolution 4.0 which emphasized the pattern of digitalization and artificial intelligence, it requires people to think more creatively, innovatively in all aspects. Then, the need for foreign language qualifications is also needed. Therefore, learning foreign languages as a provision in the era of the industrial revolution 4.0 must be prepared in the community. 
Yayasan Fajar Sejahtera Indonesia, abbreviated as YAFSI, is a private institution which is engaged in community development in the fields of education, health, and specifically the empowerment of women and child protection (Agustono et al., 2018, p. 23). In its activities, YAFSI provides many program services to the community in various regions in Medan to improve the welfare and quality of life of the community. Fields of activity include public health, economic development of the people, training, development of local institutions and so on.

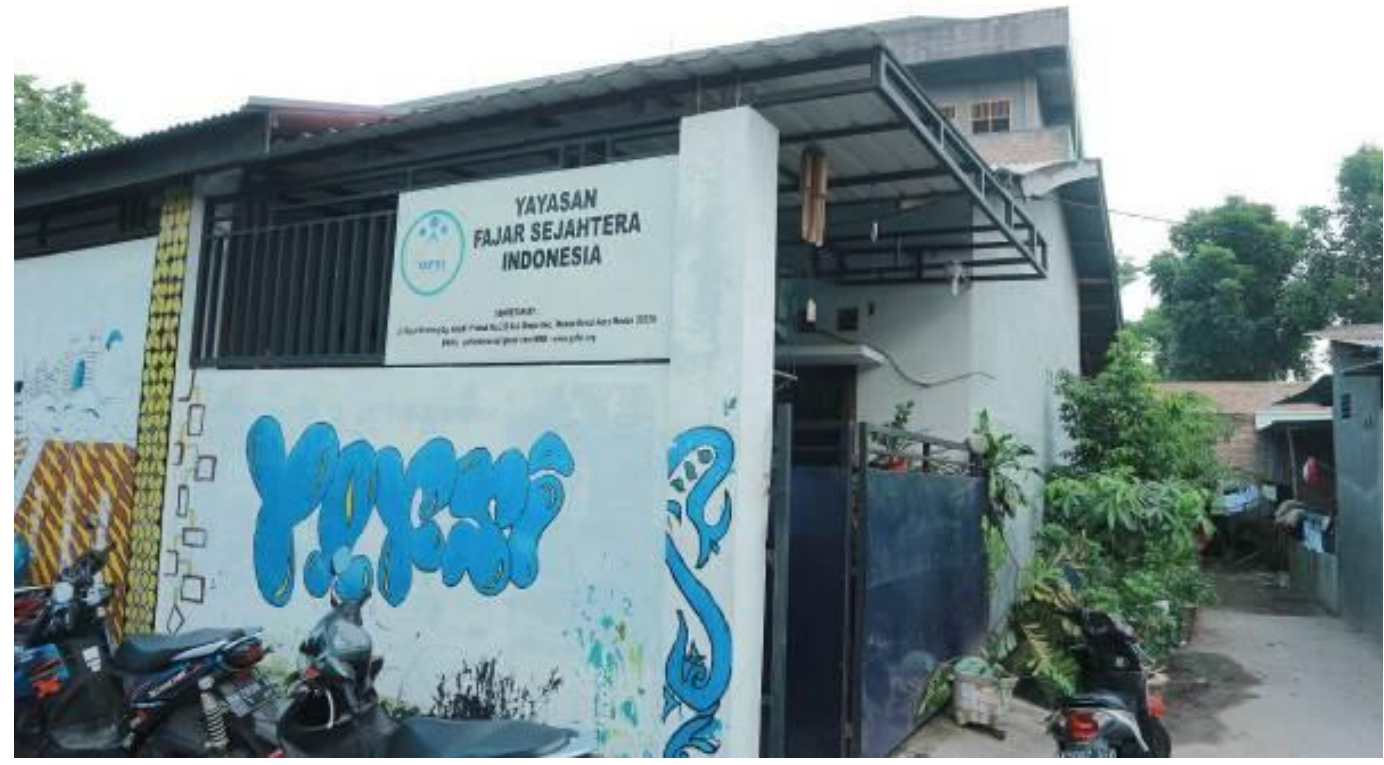

Figure 1. Secretariat of YAFSI

YAFSI has many volunteers who support its programs and activities. Volunteers who are ready to enter the community also need diverse qualifications that add value to the usefulness of volunteers in the community. One of them is the ability to speak foreign languages. It is hoped that foreign language skills possessed by YAFSI volunteers can be used not only in establishing communication, but also in being able to be taught to the community.

Japanese as one of the foreign languages which have international communication facilities with Japanese has been widely taught in Indonesia. The teaching of Japanese is not only done in formal institutions such as schools and colleges, but is also studied informally as a provision of foreign language skills for the community. The learning methods used diverse, conventional methods commonly used by teachers in formal schools besides being less attractive (Jumiati et al., 2017, p. 62), are certainly not appropriate for learning in the community. Therefore, in this activity active learning methods are used.

Studies of 'active learning' models prove that this model is able to lead to 'life skills' behavior. Unfortunately, this study has not been very well implemented in the world of formal education in Indonesia, especially the city of Medan. Life skills are not trained enough for students, as a result many students are only good at memorizing, clever in cognitive knowledge but do not have life skills such as independence, confidence, courage, responsibility, and leadership as well as the ability to observe the environment both physically and events that occur in the surrounding Environment (Kumara, 2004, p. 64). Therefore, the application of active learning is effective for learning foreign languages, especially Japanese for YAFSI volunteers.

Based on the above background, this community service is trying to provide basic level Japanese language learning (nihongo no kaiwa) through active learning for YAFSI volunteers in Medan. The formulation of the problems answered in this activity are (1) what is the effort to facilitate Japanese language learning, and how is the application of active learning in Japanese conversation learning for YAFSI volunteers? 


\section{METHOD}

In an effort to learn Japanese for the volunteers of YAFSI, the community service team will carry out Japanese language conversation training activities.

The training was carried out for 2 months involving 30 YAFSI volunteers. Determination of participants by way of interviews conducted in collaboration with YAFSI leaders as activity partner. The method used in this training activity is the lecture method, question and answer method and active learning as the main guide for teaching

\subsection{Lecture method}

The lecture method is used to provide participants with an explanation of basic knowledge of Japanese sentence patterns and vocabulary. This method also emphasizes efforts to motivate participants to have the will and increase understanding of the basics of Japanese.

\subsection{Q\&A Method}

The discussion and question and answer (Q\&A) method is important for participants to know their ability to receive explanations about basic Japanese. Through the question and answer method two-way interactions occur, between the teacher and students, which supports the achievement of optimal learning outcomes (Haryenti, 2018, p. 152). This method allows participants to explore as much knowledge as possible about Japanese conversation.

\section{3 Active Learning}

The concept of active learning, can be interpreted as a role model of learning that leads to optimizing the intellectual and emotional involvement of students in the learning process, directed to teach students how to learn to acquire and process their learning gains including knowledge, skills, attitudes and values. (Dimyati \& Mudjiono, 2012, p. 155)

Active learning is not a science and theory but is one of the strategies of student participation as students subject to the optimal way as students are able to change themselves (behavior of ways of thinking and behaving) more effectively.

Active involvement of students in the teaching process is expected to be a mental involvement (intellectual and emotional) which in some cases is followed by a physical activity. So that students really participate and actively participate in the teaching process, by placing students as the subject position, and as an important party and is the core in teaching and learning activities. (Rohani, 2004, pp. 61-65)

In essence this concept is to develop the active learning process both done by teachers or students. Active learning it seems clear that there are active instructors teaching on the one hand and students actively learning on the other. This concept is sourced from curriculum theory which is student-centered.

In the curriculum centered on students has a very important role in determining the learning material. Therefore, the activity of students is a dominant factor in teaching, because students themselves are able to make plans, determine the subject matter and features of the desired learning process. The application of active learning itself is based on Gestalt theory (insightful learning theory) which emphasizes the importance of learning through the process of gaining understanding. Learning is the result of the process of interaction between the individual and the environment. Learning is not merely an effort to respond to a stimulus but more than that. Learning is done through various activities such as experiencing, working on, and understanding learning by process. Therefore, learning outcomes will be obtained well if active students (Ali, 2007, p. 68). 


\subsubsection{Characteristics of Active Learning}

In active learning there are several indicators that influence it optimally including:

\section{1) From the Learners Aspect (Students)}

Indicators consist of (a) desires and courage in displaying their interests, needs and problems. (b) Desire and courage and opportunities for participation in preparatory activities, learning processes and continuation. (c) Appearance of various efforts or creativity of learning in undergoing and completing teaching and learning activities to achieve success. (d) Freedom to do the above without the pressure of teachers or other parties.

Learning experiences can only be obtained if students actively participate. Research in the field of education shows that passivity is a bad way of gaining learning experiences. Forms of active learning include interactions between students and teachers, students with other students, school with home, school and community. And students with all kinds of teaching tools thus students must be encouraged to participate actively so that they can learn through experience.

In language skills students should learn through actual experience, some language skills they can learn through the dramatization of role playing or discussion. Students should be given the opportunity to solve various social problems with the environment so that they find out for themselves and learn about their shortcomings. With the guidance of teachers, they can gain high awareness and carry out self-improvement and coaching on their own without being pushed or forced (Daradjat, 1996, p. 60).

\section{2) From the Teaching Aspect (Instructors)}

Consists of (a) Efforts to encourage, foster a passion for learning and actively participate students. (b) The role of the instructor does not dominate the activities of the student learning process. (c) Give students the opportunity to learn according to their ways and circumstances using several types of teaching methods and multimedia approaches.

3) From of the Teaching Program aspects

Consists of (a) teaching objectives and concepts as well as lesson content that are appropriate to the needs, interests, and abilities of students. (b) The program is quite clear, understandable and challenges students to carry out learning activities. (c) Learning material contains facts or information, concepts, principles and skills.

\section{4) From the aspect of the Teaching Situation}

(a) The condition of the instructors or teacher's close relationship with students, students with students, instructor with instructor. (b) The passion and excitement of students' learning so that they have strong motivation and discretion in developing their own ways of learning.

Teaching activities in the context of active learning certainly always involve students actively to develop abilities and reasoning such as understanding, observing, interpreting concepts, designing research, conducting research, communicating results and so on, by following procedures or steps that are orderly and in order.

The characteristics of active learning include: (1) Learning conducted is more centered on students, so that students play a more active role in developing independent learning methods, students participate in planning, implementing and evaluating the learning process, student experience more priority in deciding the starting point of the activity. (2) The instructor is a guide in the occurrence of learning experiences, the instructor is not the only source of information, the instructor is one source of learning that must provide opportunities for students to gain knowledge or skills through their own efforts, can develop motivation from within, and can develop experience to make a work. (3) The purpose of the activity is not just to 
teach academic standards, in addition to achieving academic standards, the activity is emphasized in developing the ability of students in a full and balanced manner. (4) The management of learning activities places more emphasis on the creativity and progress of students to master concepts firmly. (5) Assessment is carried out to observe and regulate the activities and progress of students and measure various skills that are not developed, for example, language skills, social skills, other skills as well as measuring student learning outcomes. (Dimyati \& Mudjiono, 2012)

\subsubsection{Focus and Directional Teaching}

Direction is a form of learning that requires teachers to ask one or several questions to track students' knowledge or get their hypotheses or conclusions. Directed teaching is that the teacher provides the main learning that will be delivered to students, then students explain according to their own answers.

In this technique, break it down into a number of categories. The directed teaching method is an exciting distraction between regular teaching methods. This method allows teachers to know what students already know and understand before explaining what the instructor teaches. This method is very useful in teaching abstract concepts.

\section{1) Procedure}

a) Asking questions or a series of questions that explore students' thinking and the knowledge they have. Use questions that have several possible answers, such as "What do you think about Japan? how is the language? say Japanese phrases that you know! "

b) Give sufficient time for students in pairs or groups to discuss their answers.

c) Telling students to return to their places and record their opinions. If possible, the selection of their answers into several separate categories related to different categories or concepts such as "family members" in the categories and positions of family members.

d) Present the main learning points that you want to teach. Instruct students to explain the suitability of their answers to these points. Record ideas that provide additional information for learning points.

\section{2) Variation}

a) Do not sort through the answers of students into separate lists. Instead, make a long list and instruct them to categorize their ideas before the teacher compares them with the concepts in your mind.

b) Begin the lesson without the categories that are already in the minds of the instructor. Look at how students and instructors together can divide their ideas into useful categories.

\subsubsection{Steps to Implement Active Learning with the Directional Teaching Model}

The steps for implementing active learning are as follows.

1) First stage: The teacher divides students into 3 heterogeneous groups of origin.

2) Second stage: The teacher asks students questions to find out the level of students' knowledge.

3) Third stage: Students discuss with their respective groups, then representatives of each group to read from the results of their discussions, alternately with other groups.

4) Stage four: The teacher records the answers from each group then gives a correct explanation about Japanese. then students are asked to correct and pronounce it correctly. 
5) Stage five: The instructor instructs students to return to their respective groups.

6) Stage six: The teacher presents the material points of Japanese sentence patterns and vocabulary.

7) Seventh stage: Each group is asked to make a conversation according to the material points that have been given.

8) Eighth: The teacher returns to explain the points of the Japanese sentence structure and vocabulary material.

9) Ninth: The instructor instructs students to work on students' worksheet assignments.

\section{RESULTS AND DISCUSSION}

\subsection{Results}

The Community service on Japanese conversation (Nihongo no Kaiwa) Basic Level training through active learning for volunteers of YAFSI in Medan is an activity that oriented in improving the quality of volunteers which is working in the social field in Medan. The activities that have been carried out are in the form of basic Japanese conversation training as well as helping to facilitate and assist the process of continuous Japanese learning.

In the initial step, the dedication team together with the dedication partners held a discussion to plan the implementation of the training and the appropriate training materials for the volunteers. Discussions were held between the community service team together with YAFSI at the YAFSI Secretariat on May 10, 2019.From the results of the discussion several decisions were taken, including the concept of training and implementation time. The training activities were carried out from 28 June 2019 to 28 July 2019 with thirty young people of YAFSI volunteers. The teaching team in the Japanese conversation training is Mr. Mhd. Pujiono, M.Hum., Ph.D. and team members who are experts in the field of Japanese language education Mrs. Murniati Br. Barus, S.Pd., M.Pd. and students of the Faculty of Cultural Sciences

In the discussion also used by the dedication team to convey the picture and orientation to the volunteers who will attend the training. The results of this review add to the reference for the team to prepare appropriate materials in the training.

\subsection{Japanese Language Conversation Training}

The training was held for the first time on June 28, 2019 at 16.00 WIB and was attended by 30 volunteers. The training is held one week two meetings so that in one month there are eight meetings.

In the training the participants actively practiced every material provided and were free to express themselves in making the desired conversation. In this way, participants can remember each expression of Japanese language that has been taught. Each training session is used by surrounding objects as the object and topic of conversation, this has also increased the creativity of the participants in making their own conversations in Japanese.

Participants enthusiastically listened and during the discussion and question and answer session, some participants asked questions related to Japanese language and culture that they already knew in the media such as television, internet, comics etc. 


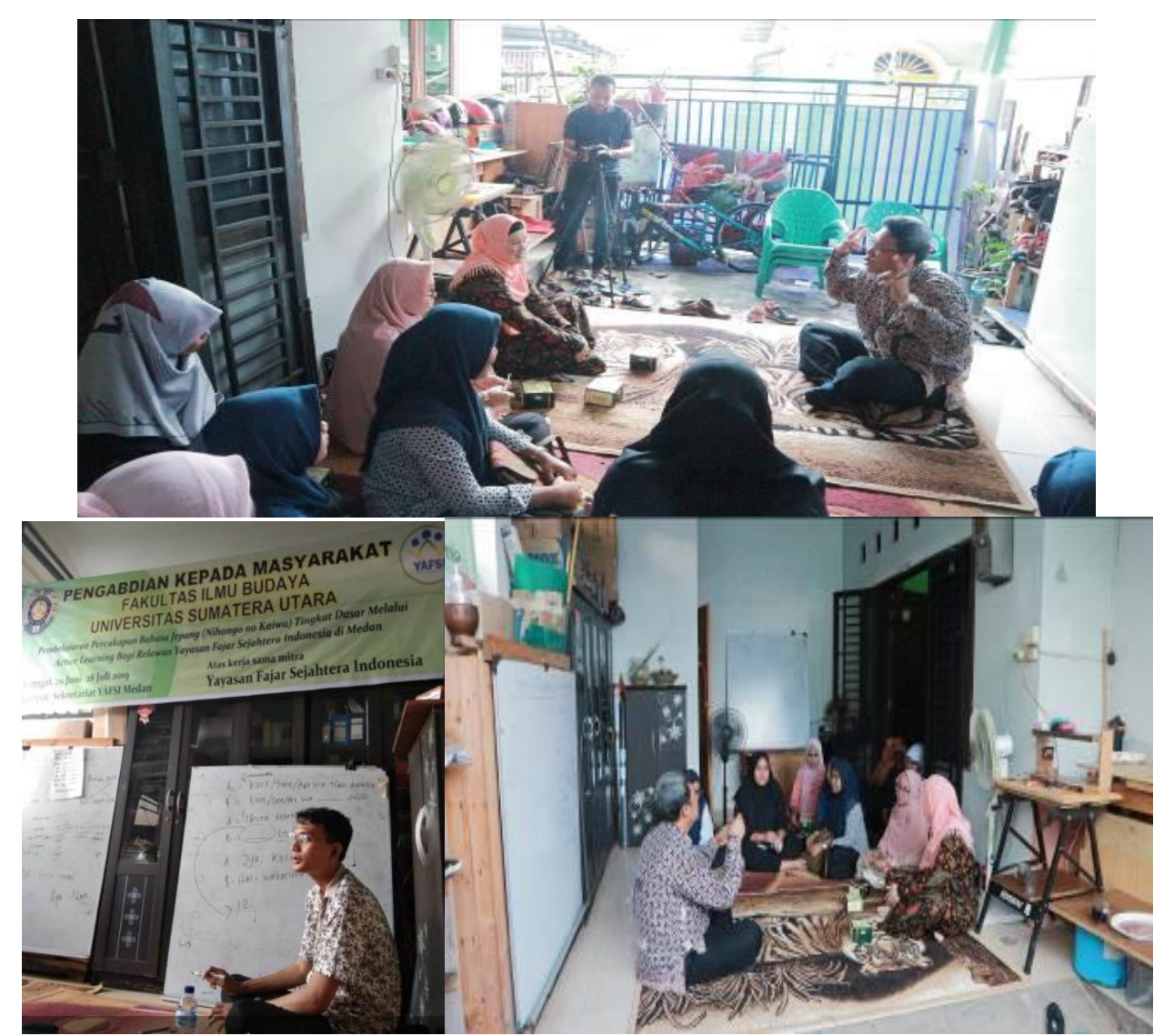

Figure 2. Training Process

\subsection{Provide Japanese learning materials}

After the training activities ended, then the symbolic handover of learning materials was carried out from the community service team at the Faculty of Cultural Sciences, University of North Sumatra with YAFSI partners represented by YAFSI chairwoman Mrs. Badriyah, S. Sos who attended the event. Henceforth items used for learning Japanese, such as blackboards, drawings etc. has been stored in the YAFSI secretariat and utilized by YAFSI in Japanese language learning activities independently.

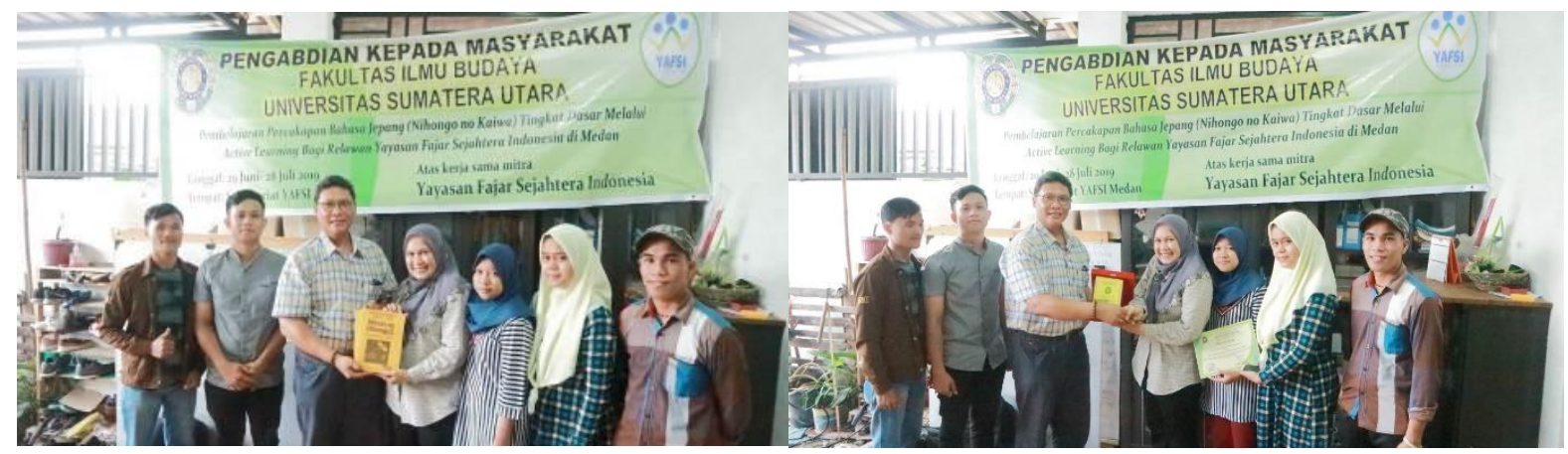

Figure 3. Provision of award plaque and books

\subsection{Output}

In this community service program, YAFSI volunteers have basic Japanese language qualifications. This is an outcome achieved by the team. The output can be seen through the results of the documentation and publication of this activity. Publication has been done through online newspapers and Youtube videos. 
Harian Analisa

Selasa, 6 Agustus 2019

Home

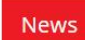

\section{Tingkatkan Kualitas, Relawan YAFSI Dilatih Bahasa Jepang}

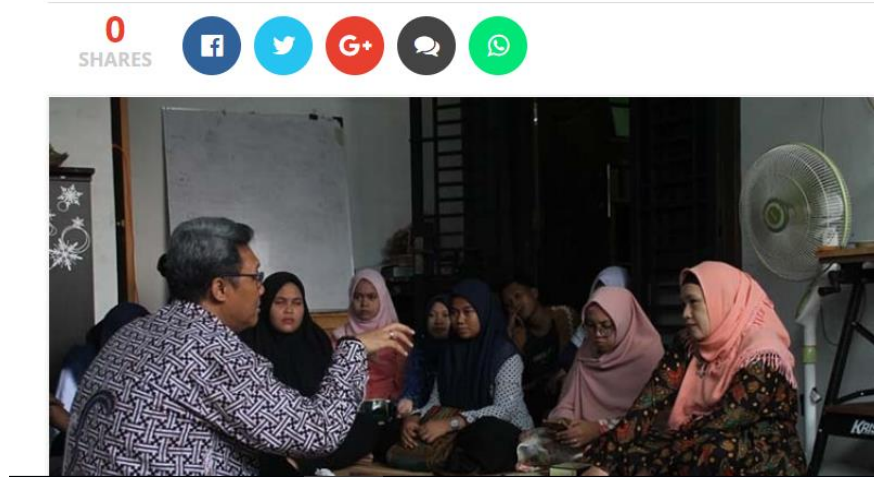

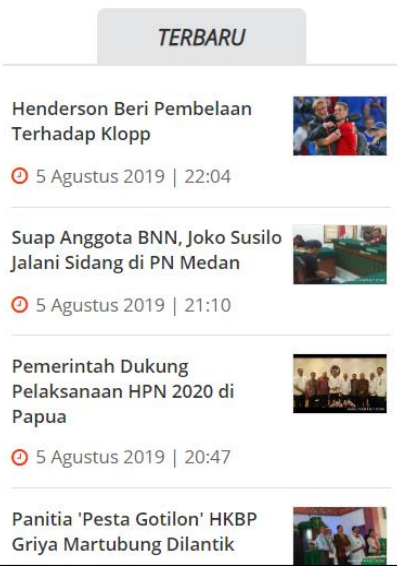

Figure 4. Online publication

\subsubsection{Making Japanese Study Guide}

Efforts to improve the Japanese language quality of YAFSI volunteers carried out by the community service team at the University of North Sumatra have reached efforts to provide teaching assistance and Japanese language learning guide materials for volunteers. by using this book, the volunteers can learn independently more easily and not forget the material that has been taught in the Japanese language training that has been carried out.

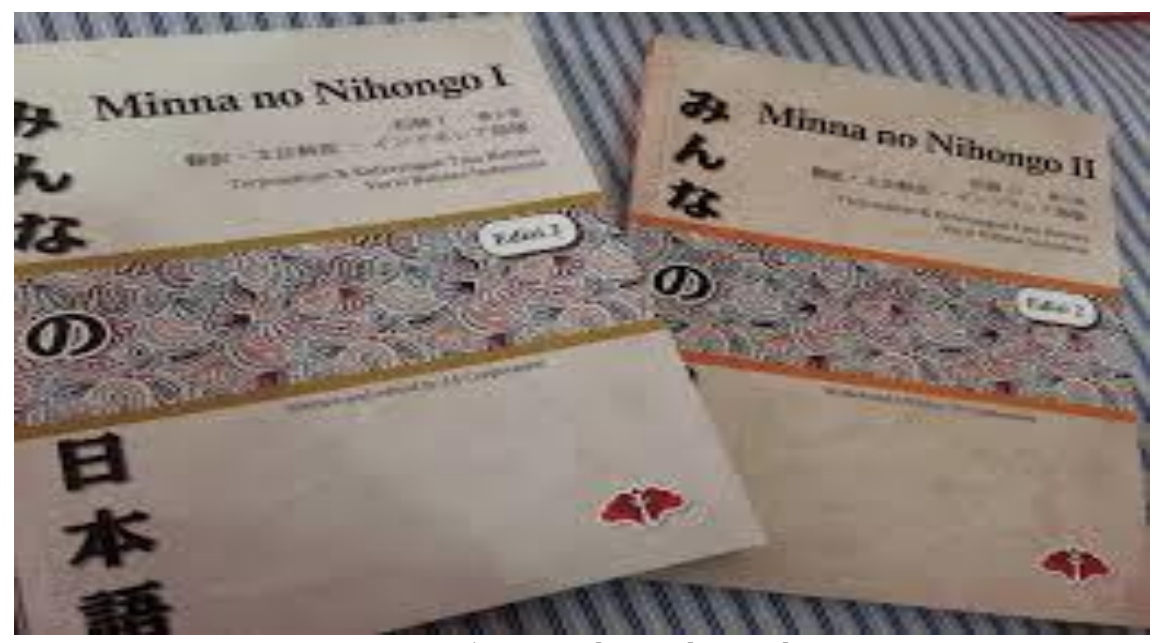

Figure 5. Example Study Guide

\section{CONCLUSION}

Efforts to improve the quality of foreign languages of YAFSI volunteers carried out by the community service team at the Faculty of Cultural Sciences, University of North Sumatra is to conduct a Japanese conversation training activity with an active learning method for one month in July 2019. Furthermore, after the socialization of the Community Service team also provided assistance to the volunteers to continue developing Japanese language skills. In an effort to facilitate Japanese language learning activities the community service team of the Faculty of 
Cultural Sciences, University of North Sumatra provided aid and learning materials such as books. This activity shows that the method of learning with active learning method is an effective method of learning Japanese. The impact was that the volunteers had knowledge of Japanese and were able to have a basic level of conversation.

\section{SUGGESTION}

The need for foreign language qualifications is needed in the era of the industrial revolution 4.0 which emphasizes the pattern of digitalization and artificial intelligence requires people to think more creatively, innovatively in all respects. Therefore, learning foreign languages as provisions for the people in the era of the industrial revolution 4.0 becomes something that must be prepared in the community. Many activities are needed that stimulate the community to intend and be enthusiastic in learning foreign languages. For this reason, the role of tertiary institutions as printers of intellectuals in various fields is important in order to improve the quality of society in foreign languages.

\section{ACKNOWLEDGMENTS}

The author would like to thank the LPM University of Sumatera Utara for providing financial support for this dedication.

\section{BIBLIOGRAPHY}

Agustono, B., Pujiono, M., \& Ayuningtias, N. (2018). IbM Pengembangan Rajutan di Kampung Aur Medan. LOGISTA - Jurnal Ilmiah Pengabdian Kepada Masyarakat, 2(1), 21. https://doi.org/10.25077/logista.2.1.21-30.2018

Ali, M. (2007). Guru dalam Proses Belajar Mengajar. Sinar Baru.

Daradjat, Z. (1996). Metodologi Pengajaran Agama Islam. Bumi Aksara.

Dimyati, \& Mudjiono. (2012). Belajar Dan Pembelajaran. Rineka Cipta.

Haryenti, H. (2018). PENINGKATAN KEMAMPUAN MENYIMAK PIDATO DENGAN METODE TANYA JAWAB SISWA KELAS IX. 2 SMP NEGERI 21 KOTA PEKANBARU. Dinamisia : Jurnal Pengabdian Kepada Masyarakat, 2(1), 150-162. https://doi.org/10.31849/dinamisia.v2i1.1083

Jumiati, J., Dinata, M., \& Sembiring, A. K. (2017). MEDIA PEMBELAJARAN INOVATIF UNTUK PROGRAM SEKOLAH ADIWIYATA. Dinamisia : Jurnal Pengabdian Kepada Masyarakat, 1(1), 61-67. https://doi.org/10.31849/dinamisia.v1i1.416

Kumara, A. (2004). Model Pembelajaran "Active Learning” Mata Pelajaran Sains Tingkat Sd Kota Yogyakarta Sebagai Upaya Peningkatan “ Life Skills ." Psikologi, 31(2), 63-91. https://doi.org/10.22146/jpsi.7060

Murti, S. (2015). Eksistensi Penggunaan Bahasa Indonesia di Era Global. Prosiding Seminar Nasional Bulan Bahasa UNIB 2015, 177-184. http://repository.unib.ac.id/11123/1/18-Sri Murti.pdf

Rohani, A. (2004). Pengelolaan Pengajaran. PT. Rineka Cipta.

Rondiyah, A. A., Wardani, N. E., \& Saddhono, K. (2017). Pembelajaran Sastra Melalui Bahasa Dan Budaya Untuk Meningkatkan Pendidikan Karakter Kebangsaan Di Era Mea (Masayarakat Ekonomi Asean). The 1st Education and Language International Conference Proceedings Center for International Language Development of Unissula, 1(1), 141-147. 